\title{
SAVE THE WHOOPING CRANE
}

The cover picture for this issue shows a striking trio of Whooping Cranes standing in a stubble field in southern Saskatchewan in a late April snowstorm. During the snow, wildlife officials, concerned for their welfare, saw that feed was put out for them and that they were able to continue their flight to the north in safety.

Each year on two occasions-during spring and fall migration-a special plea is made for safe passage for the Whooping Cranes. As they pass through the Canadian prairies and the midwestern States again this autumn, the urgent plea is repeated.

This year a new programme has been put into effect in a further effort to save the Whooping Crane from extinction. The aim of this programme is to take eggs from the nesting grounds in Wood Buffalo National Park to be hatched artificially so that the young can be reared to provide a captive breeding flock from which birds can later be released to augment the wild population.

In early June, 1967, prior to the appearance of any young on the breeding grounds, a team of Canadian and United-States biologists arranged to pick up eggs from six nests and fly them to a special rearing station at Patuxent, Maryland. CWS biologist Ernie Kuyt, known to Blue Jay readers as a contributor to the magazine and as one of the Society's directors, waded out to the nests from a helicopter that had landed carefully nearby. From each clutch of two eggs, one egg was taken, and later fieldchecking has established that the taking of these eggs did not affect the normal hatching of the remaining eggs. Five of the six eggs taken hatched successfully at Patuxent, one of these being a young bird with a weak leg joint. which responded to treatment whereas it would have perished in the wild.

The plan to' start a captive breeding flock of Whooping Cranes was imple- mented this year only after long con sideration by Canadian and Uniter States wildlife biologists. As early as 1961, when the Whooping Crane Con servation Association was established, that organization of interested people had expressed the belief that captive propagation was the only salvation for the Whooping Crane. A few years later, the U.S. Fish and Wildlife Service and the Canadian Wildlife Service issued a joint proposal to increase the Whooping Crane population by collecting a limited number of eggs from nests in Canada in wet years when experience has shown the mortality of the young to be highest. However, they did not wish to rush into this programme without adequate preliminary study. In the meantime the U.S. Government had made grants to the Bureau of Sport Fisheries and Wildlife for its special project of protecting rare and endangered species, and experiments were being carried on with Sandhill Cranes at the Patuxent Wildlife Research Center. As a result of these studies, the plan to take eggs was finally put into effect this year and the long term project of raising a captive flock is now under way.

It is therefore of special interest to us to learn that Mr. Fred Bard, Director of the Saskatchewan Museum of Natural History, has been chosen President of the Whooping Crane Conservation Association for 1968. Membership in this association is invited from all people interested in helping to save the Whooping Crane. Individual memberships at $\$ 3.00$ per annum are available from the Chairman of the Membership Committee, at the following address:

\section{Mr. C. S. Williams \\ 17 A Amanda St. \\ Orangeville, Ontario.}

Three dollars contributed to this cause will help support the publicity and the research necessary to protect our Whooping Cranes. 


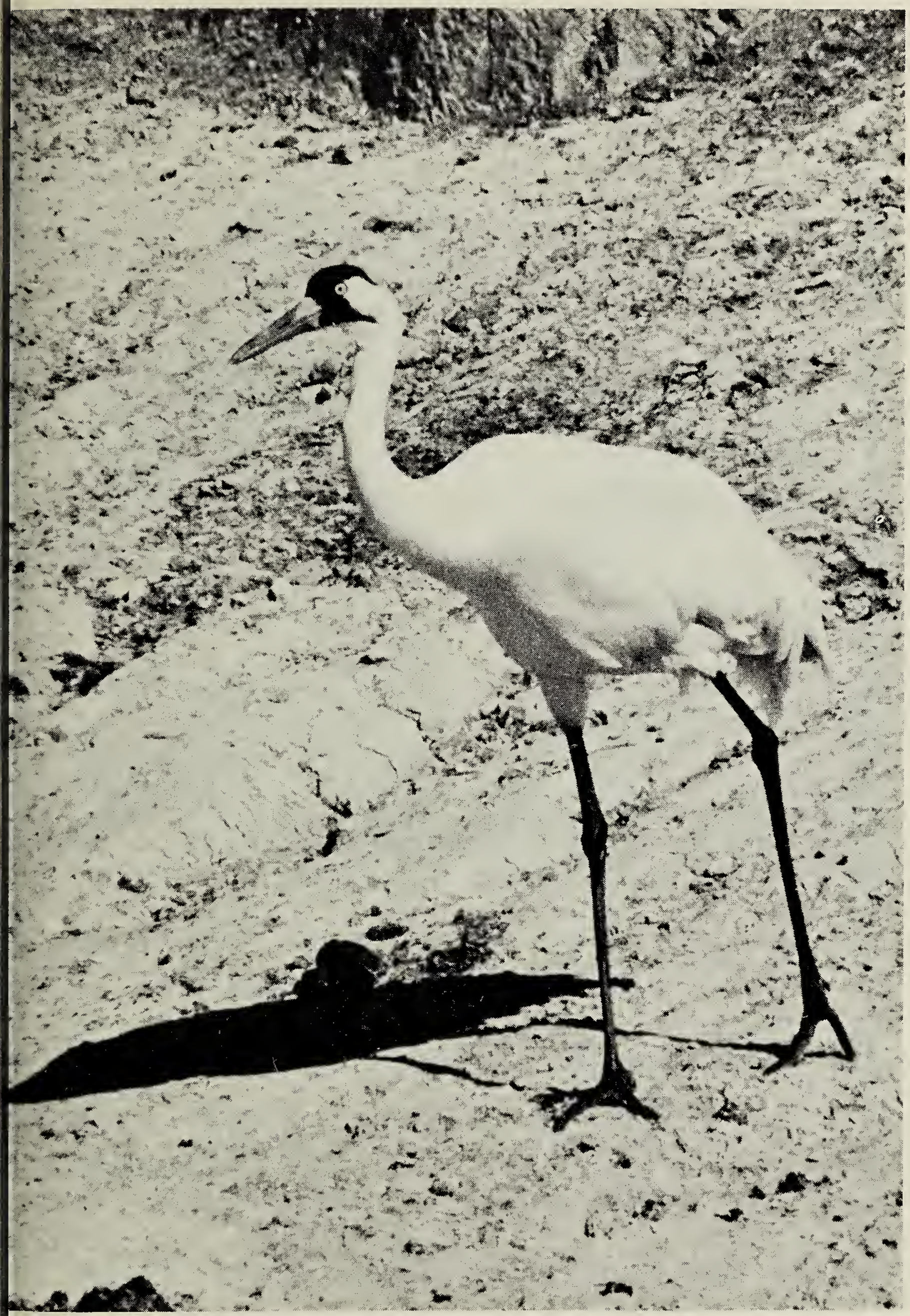

Photo by Luther Goldman

Courtesy United States Department of the Interior, Fish and Wildlife Service

dult Whooping Crane on wintering grounds

t Aransas National Wildlife Refuge, Texas 